\title{
DECISION SUPPORT SYSTEM FOR EMPLOYEE EMPLOYMENT REMAINS USING PROFILE MATCHING METHOD IN PT. HYPER MEGA SHIPPING
}

\author{
Frasstio Agustin', Santoso Setiawan² \\ Information Systems \\ Sekolah Tinggi Manajemen Informatika dan Komputer Nusa Mandiri, Jakarta, Indonesia \\ http://www.nusamandiri.ac.id \\ frasstioagustin@gmail.com ${ }^{1}$, santoso.sts@nusamandiri.ac.id ${ }^{2}$
}

\begin{abstract}
Abstrak
Perusahaan merupakan tempat terjadinya produksi, dimana manusia berfungsi sebagai tenaga penggerak dan pelaksana untuk mewujudkan tujuan perusahaan yang telah ditetapkan sebelumnya. Setiap karyawan di sebuah perusahaan tentunya selalu berusaha meningkatkan kemampuan dan prestasinya. Sehingga dia bisa mendapatkan jenjang karir yang bagus sesuai idamannya. Untuk memudahkan pelaksanaan proses pengangkatan karyawan tetap dari setiap karyawan maka dibuat sebuah sistem pendukung keputusan yang bertujuan memudahkan proses tersebut. Salah satu metode yang digunakan dalam pengambilan keputusan pengangkatan karyawan tetap adalah Profile Matching. Sistem pendukung keputusan untuk proses Profile Matching dan analisis gap ini dibuat berdasarkan data di PT. Hyper Mega Shipping, Metode Profile Matching dilakukan untuk menentukan pengangkatan karyawan tetap berdasarkan pada dua aspek yaitu Kinerja dan Budaya kerja. Hasil dari proses seleksi berupa skor akhir karyawan sebagai rekomendasi bagi pengambil keputusan untuk menentukan karyawan mana saja yang akan mendapatkan promosi pengangkatan karyawan tetap.
\end{abstract}

Kata kunci: Sistem Pendukung Keputusan Pengangkatan Karyawan Tetap Menggunakan Metode Profile Matching Di PT. Hyper Mega Shipping.

\begin{abstract}
The company is a place of production, where humans function as a driving force and executor to realize the company's goals that have been set previously. Every employee in a company must always try to improve their abilities and achievements. So he can get a good career path according to his dream. To facilitate the implementation of the permanent employee appointment process of each employee, a decision support system is created which aims to facilitate the process. One of the methods used in making decisions on the appointment of permanent employees is Profile Matching. The decision support system for the Profile Matching and gap analysis process is based on data at PT. Hyper Mega Shipping, Profile Matching Method is carried out to determine the appointment of permanent employees based on two aspects, namely Performance and Work Culture. The results of the selection process in the form of a final employee score as a recommendation for decision-makers to determine which employees will get the promotion of permanent employee appointments.
\end{abstract}

Keywords: Decision Support System for Permanent Employee Appointment Using Profile Matching Method in PT. Hyper Mega Shipping.

\section{INTRODUCTION}

Advances in Technology and Information provide a place for progress in the global industry and business that has a function as Planning and Decision (Purwanto, 2017), where information technology enters a more strategic role because of its existence as a provider of a company's business plan and is an additional piece of information for company leaders who are confronted with reality to make a number of important decisions.
Sophisticated technology without being matched by good Human Resources will be in vain. The selection of leaders or leaders of various best employee candidates becomes an objective reference to determine the leader who will fill a position. Recommendations from leaders or coworkers to assess employees who will become leaders are not a guarantee and are still subjective (Handayani, 2017) (Sinurat, Irawan, Dewi, Andani, \& Fauzan, 2019). There needs to be a change in ways and methods as an alternative to the 
selection of leaders according to needs. In this study, the Profile Matching method was chosen to provide assessment and evaluation of employee performance to be promoted to become a Leader (Purwanto, 2017).

One example will be discussed on how to appoint permanent employees at PT. Hyper Mega Shipping in accordance with the criteria of absenteeism and timeliness, aspects of performance, aspects of work culture, and managerial ability of work that exist in a particular position, then if there is a position on the part of a company that requires an employee or is usually said to be empty, then, in this case, the task is to carry out an analysis of the employees of PT. Hyper Mega Shipping which according to the calculation matches the criteria of the position, at PT. Hyper Mega Shipping. (Pratiwi, 2016) GAP competency analysis (Profile Matching). This competency system is one of the solutions to human resource assets and there is a description of the achievements and potential of human resources according to the work unit. Employee achievement and potential can be seen whether the competency is in accordance with the work duties they have. PT. Hyper Mega Shipping implements the appointment of permanent employees on the basis of performance and works culture on employees (Pratiwi, 2016)., currently, competency GAP analysis is still done manually (Ramadhan, Yuniati, \& Bakar, 2014), (Indriyani, 2019). The process of carrying out the assessment will produce a grade from several candidates, which later this grade can be the basis for the appointment of PT. Hyper Mega Shipping to be appointed as organic or permanent employees according to company needs. The final decision still lies with the leadership of the company. In the profile matching process, it is broadly a process of comparing individual competencies into position competencies so that competency differences can be known (also called gaps) (Tharo \& Utama Siahaan, 2016), the smaller the gap produced, the greater the value weights which means it has a greater chance for employees to occupy that position.

To facilitate the implementation of the permanent employee hiring process for each employee, a decision-making system is created that aims to facilitate the process. Decision Support System or also known as SPK is part of a computerbased information system. There are several stages in the decision support system, namely defining the problem, collecting relevant data, processing data into information, and determining alternative solutions. One method used in making promotion decisions is Profile Matching. Because the Profile
Matching method can provide maximum results, valid data, and time-efficient (Sunarti, 2017).

Because of the problems in PT. Hyper Mega Shipping is valued subjectively namely, the close relationship with superiors, a decision support system is built, so that it can provide solutions, How is the selection process for the appointment of permanent employees of PT. Hyper Mega Shipping Jakarta using the Profile Matching method. How to make a decision support system that helps to determine the appointment of permanent employees, determine the weight of the Gap value, grouping core factors, and secondary factors, calculating the total value, and finally determining the ranking.

The purpose of this study is to create a decision support system that helps to determine the appointment of permanent employees at PT. Hyper Mega Shipping. Speed up the accuracy and selection process relevant to the appointment of permanent employees by using the Profile Matching method.

\section{RESEARCH METHODS}

The author obtained data by conducting research directly at PT. Hyper Mega Shipping so as to get good and correct data with the following data collection models:

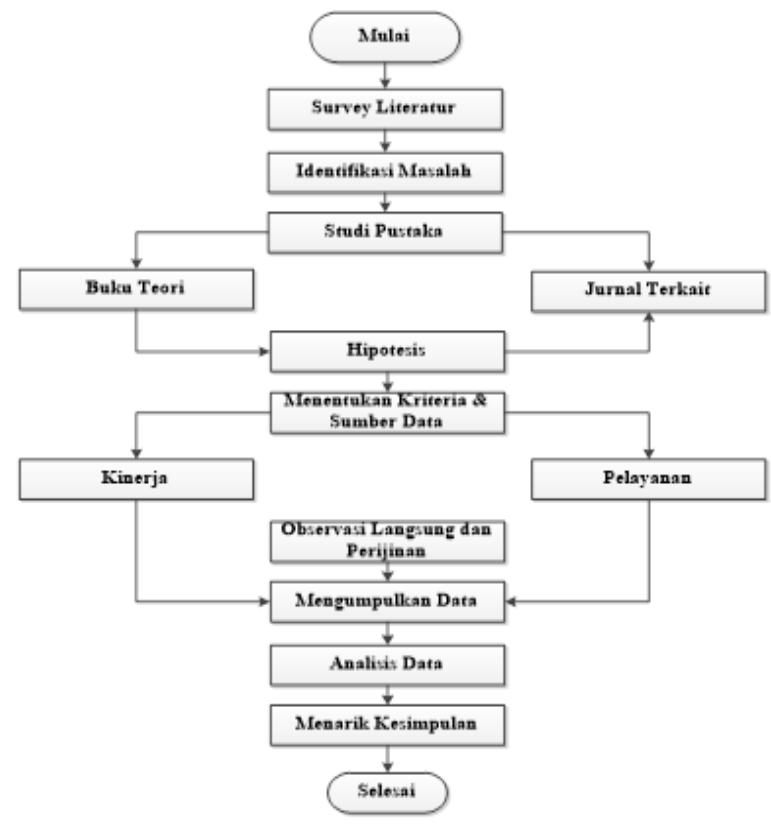

Sources: (Sugiyono, 2017)

Gambar1 Tahapan Penelitian

\section{Literature Survey}


In this initial stage, the researchers collected material in the form of literature and related information.

\section{Identification of problems}

Continue the research by identifying the issues to be discussed, relating to the Decision Support System for permanent employee appointments using the Profile Matching Method at PT. Hyper Mega Shipping based on literature and information obtained.

\section{Literature review}

Researchers study the literature in the form of theoretical books about the Decision Support System and Profile Matching Method which will be used as a theoretical study in research.

\section{Hypothesis}

There is no influence of the criterion data used in the appointment of permanent employees of PT. Hyper Mega Shipping.

The influence of the criterion data used in the appointment of permanent employees of PT. Hyper Mega Shipping.

\section{Determine Criteria and Data Sources}

Researchers determine the criteria of the decision support system for permanent employee appointments using the Profile Matching Method at PT. Hyper Mega Shipping from the aspect of performance and aspects of work culture. Then determine what data are needed based on population, sample and sampling method. Then determine the research subject.

\section{Direct Observation and Licensing}

Researchers directly came to PT. Hyper Mega Shipping and ask permission from relevant parties and authorities.

\section{Collecting data}

At this stage, it is done by observation and interviews with IT Managers and by collecting documents that can be used as a source of research.

\section{Data analysis}

In this stage, data from aspects of performance and aspects of work culture will be analysed data analysis will be performed using the Profile Matching method. The Profile Matching method is included in the descriptive quantitative research where the Profile Matching method will calculate the numbers in the data from the performance aspects and aspects of the work culture of the employees of PT. Hyper Mega Shipping.

\section{Draw a conclusion}

The researcher draws a conclusion based on the analysis of data in the previous chapters and checks whether the conclusion is in accordance with the hypothesis, the aims, and objectives of the study. Besides providing suggestions that can be used as input for related companies to be utilized further

\section{RESEARCH RESULTS AND DISCUSSION}

In the assessment of the appointment of permanent employees, using the Profile Matching method, several aspects are assessed and from these aspects there are sub criteria, namely as follows:

Table 1 Aspects of Appointment of Permanent Employees

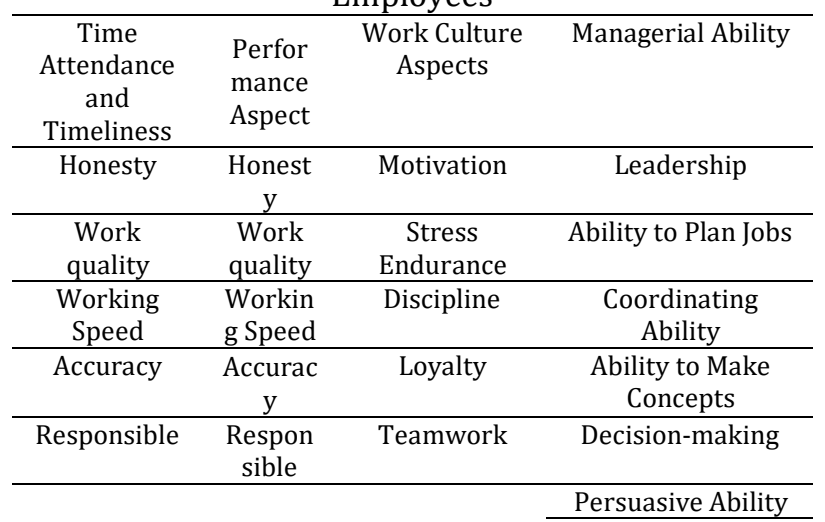

Sources: (Agustin, 2019)

Table 2. Value Range

\begin{tabular}{cl}
\hline Range & Great Value \\
\hline$<64$ & $1=$ Very Poor \\
\hline $65-74$ & $2=$ less \\
\hline $75-84$ & $3=$ Enough \\
\hline $85-94$ & $4=$ good \\
\hline $95-100$ & $5=$ Very Good \\
\hline
\end{tabular}

Sources: (Agustin, 2019)

\section{GAP Competency Mapping}

Before calculating the competency gap value of all employee candidates who will be recruited permanent employees, below is a table of values from the Performance Aspects and Work Culture Aspects.

Table 3 Value of Performance Aspects 


\begin{tabular}{ccccccc}
\hline \multicolumn{7}{c}{ The performance } \\
\hline No & Nik & KN01 & KN02 & KN03 & KN04 & KN05 \\
\hline 1 & 001.17 .00034 & 90 & 95 & 89 & 91 & 84 \\
\hline 2 & 001.17 .00030 & 89 & 84 & 80 & 90 & 86 \\
\hline 3 & 001.16 .00007 & 79 & 85 & 90 & 89 & 83 \\
\hline 4 & 004.17 .00029 & 85 & 83 & 95 & 84 & 80 \\
\hline 5 & 001.18 .00035 & 96 & 83 & 79 & 90 & 89 \\
\hline 6 & 004.18 .00030 & 79 & 84 & 95 & 86 & 90
\end{tabular}

Sources: (Agustin, 2019)

Information :

KN01: Honesty

KN02: Quality of Work

KN03: Working Speed

KN04: Accuracy

KN05: Responsibility

Table 4. Value of Aspects of Work Culture

\begin{tabular}{ccccccc}
\hline \multicolumn{7}{c}{ Work Culture } \\
\hline No & Nik & BK01 & BK02 & BK03 & BK04 & BK05 \\
\hline 1 & 001.17 .00034 & 88 & 93 & 85 & 86 & 87 \\
\hline 2 & 001.17 .00030 & 86 & 89 & 80 & 83 & 88 \\
\hline 3 & 001.16 .00007 & 81 & 79 & 84 & 79 & 77 \\
\hline 4 & 004.17 .00029 & 83 & 90 & 83 & 88 & 95 \\
\hline 5 & 001.18 .00035 & 78 & 90 & 81 & 84 & 89 \\
\hline 6 & 004.18 .00030 & 80 & 90 & 95 & 81 & 96
\end{tabular}

Sources: (Agustin, 2019)

Information :

BK01: Motivation

BK02: Stress Resistance

BK03: Discipline

BK04: Teamwork

BK05: Loyalty

In calculating the competency gap mapping, what is meant by the gap here is the difference between the coordinator profile and the employee profile or can be seen in the formula below:

$$
\text { Gap = Employee Profile - Job Profile }
$$

The calculation of competency gap mapping is based on existing aspects, the following is the calculation.

\section{Mapping Competency Gap Performance Aspects}

Table 5. The gap in Performance Aspects

\begin{tabular}{ccccccc}
\hline \multicolumn{7}{c}{ The performance } \\
\hline No & Nik & KN01 & KN02 & KN03 & KN04 & KN05 \\
\hline 1 & 001.17 .00034 & 4 & 5 & 4 & 4 & 3 \\
\hline 2 & 001.17 .00030 & 4 & 3 & 3 & 4 & 4 \\
\hline 3 & 001.16 .00007 & 3 & 4 & 4 & 4 & 3 \\
\hline 4 & 004.17 .00029 & 4 & 3 & 5 & 3 & 3 \\
\hline 5 & 001.18 .00035 & 5 & 3 & 3 & 4 & 4 \\
\hline 6 & 004.18 .00030 & 3 & 3 & 5 & 4 & 4 \\
\hline & Profil Jabatan & 4 & 4 & 4 & 4 & 4 \\
\hline
\end{tabular}

\begin{tabular}{cclllll}
\hline \multicolumn{7}{c}{ The performance } \\
\hline No & Nik & KN01 & KN02 & KN03 & KN04 & KN05 \\
\hline 1 & 001.17 .00034 & 0 & 1 & 0 & 0 & -1 \\
\hline 2 & 001.17 .00030 & 0 & -1 & -1 & 0 & 0 \\
\hline 3 & 001.16 .00007 & -1 & 0 & 0 & 0 & -1 \\
\hline 4 & 004.17 .00029 & 0 & -1 & 1 & -1 & -1 \\
\hline 5 & 001.18 .00035 & 1 & -1 & -1 & 0 & 0 \\
\hline 6 & 004.18 .00030 & -1 & -1 & 1 & 0 & 0 \\
\hline \multicolumn{7}{l}{ Sources: (Agustin, 2019) }
\end{tabular}

Based on the results of the calculation of the performance aspects of table 5 it can be seen the gap or the difference between the profiles needed for each candidate.

\section{Mapping the Competency Gap of Work Culture Aspects}

Table 6 Gap Aspects of Work Culture

\begin{tabular}{ccccccc}
\hline \multicolumn{7}{c}{ Work Culture } \\
\hline No & Nik & BK01 & BK02 & BK03 & BK04 & BK05 \\
\hline 1 & 001.17 .00034 & 4 & 4 & 4 & 4 & 4 \\
\hline 2 & 001.17 .00030 & 4 & 4 & 3 & 3 & 4 \\
\hline 3 & 001.16 .00007 & 3 & 3 & 3 & 3 & 3 \\
\hline 4 & 004.17 .00029 & 3 & 4 & 3 & 4 & 5 \\
\hline 5 & 001.18 .00035 & 3 & 4 & 3 & 3 & 4 \\
\hline 6 & 004.18 .00030 & 3 & 4 & 5 & 3 & 5 \\
\hline & Profil Jabatan & 4 & 4 & 4 & 4 & 4 \\
\hline 1 & 001.17 .00034 & 0 & 0 & 0 & 0 & 0 \\
\hline 2 & 001.17 .00030 & 0 & 0 & -1 & -1 & 0 \\
\hline 3 & 001.16 .00007 & -1 & -1 & -1 & -1 & -1 \\
\hline 4 & 004.17 .00029 & -1 & 0 & -1 & 0 & 1 \\
\hline 5 & 001.18 .00035 & -1 & 0 & -1 & -1 & 0 \\
\hline 6 & 004.18 .00030 & -1 & 0 & 1 & -1 & 1 \\
\hline
\end{tabular}

Sources: (Agustin, 2019)

Based on the calculation of Work Culture aspects from table 6, it can be seen the gap or the difference between the profiles needed for each candidate.

\section{Determination of Weight Value Gap}

Table 7 Weight Gap Value

\begin{tabular}{llll}
\hline No & Difference & $\begin{array}{l}\text { Value } \\
\text { Weight }\end{array}$ & Information \\
\hline 1. & 0 & 5 & $\begin{array}{l}\text { There is no difference } \\
\text { (Competency according to what } \\
\text { is needed }\end{array}$ \\
\hline 2. & 1 & 4,5 & $\begin{array}{l}\text { Competence individual excess } \\
\text { of a level 1 / level }\end{array}$ \\
\hline 3. & -1 & 4 & $\begin{array}{l}\text { Competence individual } \\
\text { shortage 1 level / level }\end{array}$ \\
\hline 4. & 2 & 3,5 & $\begin{array}{l}\text { Competence individual excess 2 } \\
\text { level / level }\end{array}$ \\
\hline 5. & -2 & 3 & $\begin{array}{l}\text { Competence individual } \\
\text { shortage 2 level / level }\end{array}$ \\
\hline 6. & 3 & 2,5 & $\begin{array}{l}\text { Competence individual excess 3 } \\
\text { levels / level }\end{array}$ \\
\hline 7. & -3 & 2 & $\begin{array}{l}\text { Competence individual } \\
\text { shortage 3 levels / level }\end{array}$ \\
\hline 8. & 4 & 1,5 & $\begin{array}{l}\text { Competence individual excess 4 } \\
\text { levels / level }\end{array}$ \\
\hline
\end{tabular}




\begin{tabular}{|c|c|c|c|}
\hline 9. & -4 & 1 & $\begin{array}{l}\text { Competence individual } \\
\text { shortage of } 4 \text { levels / level }\end{array}$ \\
\hline
\end{tabular}

After getting a gap on each employee, each employee's profile is given a weighted value based on the weighted value gap table which can be seen in table 7. The following is the determination of the weights in the Performance Aspect Assessment of Employees and Work Culture

Table 8 Weight of Performance Aspects

\begin{tabular}{|c|c|c|c|c|c|c|}
\hline \multirow[b]{2}{*}{ No } & \multicolumn{6}{|c|}{ Kinerja } \\
\hline & Nik & KN01 & KN02 & KN03 & KN04 & KN05 \\
\hline 1 & 001.17 .00034 & 0 & 1 & 0 & 0 & -1 \\
\hline 2 & 001.17.00030 & 0 & -1 & -1 & 0 & 0 \\
\hline 3 & 001.16 .00007 & -1 & 0 & 0 & 0 & -1 \\
\hline 4 & 004.17 .00029 & 0 & -1 & 1 & -1 & -1 \\
\hline 5 & 001.18 .00035 & 1 & -1 & -1 & 0 & 0 \\
\hline 6 & 004.18 .00030 & -1 & -1 & 1 & 0 & 0 \\
\hline 1 & 001.17 .00034 & 5 & 4,5 & 5 & 5 & 4 \\
\hline 2 & 001.17.00030 & 5 & 4 & 4 & 5 & 5 \\
\hline 3 & 001.16 .00007 & 4 & 5 & 5 & 5 & 4 \\
\hline 4 & 004.17 .00029 & 5 & 4 & 4,5 & 4 & 4 \\
\hline 5 & 001.18 .00035 & 4,5 & 4 & 4 & 5 & 5 \\
\hline 6 & 004.18 .00030 & 4 & 4 & 4,5 & 5 & 5 \\
\hline
\end{tabular}

Tabel 9. Bobot Nilai Aspek Budaya Kerja

\begin{tabular}{ccccccc}
\hline \multicolumn{7}{c}{ Budaya Kerja } \\
\hline No & Nik & BK01 & BK02 & BK03 & BK04 & BK05 \\
\hline 1 & 001.17 .00034 & 0 & 0 & 0 & 0 & 0 \\
\hline 2 & 001.17 .00030 & 0 & 0 & -1 & -1 & 0 \\
\hline 3 & 001.16 .00007 & -1 & -1 & -1 & -1 & -1 \\
\hline 4 & 004.17 .00029 & -1 & 0 & -1 & 0 & 1 \\
\hline 5 & 001.18 .00035 & -1 & 0 & -1 & -1 & 0 \\
\hline 6 & 004.18 .00030 & -1 & 0 & 1 & -1 & 1 \\
\hline
\end{tabular}

\begin{tabular}{ccccccc}
\hline \multicolumn{7}{c}{ Budaya Kerja } \\
\hline No & Nik & BK01 & BK02 & BK03 & BK04 & BK05 \\
\hline & & & & & & \\
\hline 1 & 001.17 .00034 & 5 & 5 & 5 & 5 & 5 \\
\hline 2 & 001.17 .00030 & 5 & 5 & 4 & 4 & 5 \\
\hline 3 & 001.16 .00007 & 4 & 4 & 4 & 4 & 4 \\
\hline 4 & 004.17 .00029 & 4 & 5 & 4 & 5 & 4,5 \\
\hline 5 & 001.18 .00035 & 4 & 5 & 4 & 4 & 5 \\
\hline 6 & 004.18 .00030 & 4 & 5 & 4,5 & 4 & 4,5 \\
\hline
\end{tabular}

Sources: (Agustin, 2019)

Based on the results of calculations in Tables 8 and 9, weigh the value of the Performance aspects and Work Culture aspects values for each candidate

\section{Calculation and Classification of Core Factors and Secondary Factors}

After determining the weight of the gap value for each aspect of the Employee Performance Assessment, then each aspect is divided into two, namely core factor and secondary factor, core Factor obtained from 3 main sub-criteria namely KN01, KN02, KN03 and Secondary Factor obtained from 2 sub-criteria namely KN04 and KN05. Then the Core Factor and Secondary Factor values are added according to the formula and the results can be seen in the table. Here's how to calculate:

$N C F: \frac{\sum N C(k n 1, k n 2, k n 3)}{\sum I C}$

$N S F: \frac{\sum N S(k n 4, k n 5)}{\sum I S}$

Information :

NCF : Average Factor Value

NC : Total Number of Core Factor Values

IC : Number of Core Factor items

NSF : Average Secondary Factor Score

NS : Total Number of Secondary Factor Values

IS : Number of Secondary Factor items

Table 10 Value of CF and SF Performance Aspects

\begin{tabular}{ccrrrrrrr}
\hline & \multicolumn{1}{c}{ Variable } & KN02 & KN03 & KN04 & KN05 & \multicolumn{1}{c}{ CF } & SF \\
\hline No & Nik & KN01 & KN02 & 5,83 & 4,5 \\
\hline 1 & 001.17 .00034 & 5 & 4,5 & 5 & 5 & 4 & 4,83 & 5 \\
\hline 2 & 001.17 .00030 & 5 & 4 & 4 & 5 & 5 & 4,33 \\
\hline 3 & 001.16 .00007 & 4 & 5 & 5 & 5 & 4 & 4,67 & 4,5 \\
\hline 4 & 004.17 .00029 & 5 & 4 & 4,5 & 4 & 4 & 4,5 & 4 \\
\hline 5 & 001.18 .00035 & 4,5 & 4 & 4 & 5 & 5 & 4,167 & 5 \\
\hline 6 & 004.18 .00030 & 4 & 4 & 4,5 & 5 & 5 & 4,167 & 5 \\
\hline
\end{tabular}


Sources: (Agustin, 2019)

Based on the calculation of Core Factor and Secondary Factor for the performance aspects, the values for each candidate in Table 10 are obtained.

\section{Value of Core Factor and Secondary Factor Aspects of Work Culture}

Core Factor is obtained from 3 main sub-criteria namely BK01, BK02, BK03 and Secondary Factor obtained from the remaining 2 sub-criteria namely BK04 and BK05. Then the Core Factor and Secondary Factor values are added according to the formula and the results can be seen in the table. Here's how to calculate:

$N C F: \frac{\sum N C(b k 1, b k 2, b k 3)}{\sum I C}$

$N S F: \frac{\sum N S(b k 4, b k 5)}{\sum I S}$

Information :

NCF : Average Factor Value

NC : Total Number of Core Factor Values

IC : Number of Core Factor items

NSF : Average Secondary Factor Score

NS : Total Number of Secondary Factor Values

IS : Number of Secondary Factor items

Table 11. Value of CF and SF Aspects of Work

\begin{tabular}{|c|c|c|c|c|c|c|c|c|}
\hline \multicolumn{9}{|c|}{ Culture } \\
\hline $\mathrm{N}$ & & BK & BK & $\mathrm{BK}$ & BK & BK & & \\
\hline o & Nik & 01 & 02 & 03 & 04 & 05 & $\mathrm{CF}$ & SF \\
\hline & 001.17 .00 & & & & & & & \\
\hline 1 & 034 & 5 & 5 & 5 & 5 & 5 & 5 & 5 \\
\hline & 001.17 .00 & & & & & & 4,6 & \\
\hline 2 & 030 & 5 & 5 & 4 & 4 & 5 & 7 & 4,5 \\
\hline & 001.16 .00 & & & & & & & \\
\hline 3 & 007 & 4 & 4 & 4 & 4 & 4 & 4 & 4 \\
\hline & 004.17 .00 & & & & & & 4,3 & 4,7 \\
\hline 4 & 029 & 4 & 5 & 4 & 5 & 4,5 & 3 & 5 \\
\hline & 001.18 .00 & & & & & & 4,3 & \\
\hline 5 & 035 & 4 & 5 & 4 & 4 & 5 & 3 & 4,5 \\
\hline & 004.18 .00 & & & & & & & 4,2 \\
\hline 6 & 030 & 4 & 5 & 4,5 & 4 & 4,5 & 4,5 & 5 \\
\hline
\end{tabular}

Sources: (Agustin, 2019)

Based on the calculation of Core Factor and Secondary Factor for aspects of work culture, the values for each candidate in Table 11 are obtained.

\section{Calculation of Total Value}

From the results of the calculation of core factors and secondary factors from each aspect, then the total value is calculated. The calculation can be seen with the formula below:

$N(k n, b k)=$

$(x) \% N C F(k n, b k)+(x) \% N S F(k n, b k)=$ $N(k n, b k)$

Information:

$\mathrm{N}(\mathrm{kn}, \mathrm{bk})$ : Total value of aspects (Performance, work culture)

(x)\% : The percent value inputted

NCF $(\mathrm{kn}, \mathrm{bk})$ : Average Factor Core Value (Performance, work culture)

NSF (kn, bk) : Average Secondary Factor Value (Performance, work culture)

Based on the formula for calculating the total value above, we can calculate the total value of each aspect. The following are calculations from the aspect of performance:

$$
\begin{aligned}
& N(k n)=(x) \% N C F(k n, b k)+(x) \% N S F(k n, b k)= \\
& N(k n, b k)
\end{aligned}
$$

\begin{tabular}{|c|c|c|c|c|}
\hline \multicolumn{5}{|c|}{ Work Culture } \\
\hline No & Nik & $\mathrm{CF}$ & SF & $\mathrm{N}(\mathrm{kn})$ \\
\hline 1 & 001.17 .00034 & 4,83 & 4,5 & 4,71 \\
\hline 2 & 001.17 .00030 & 4,33 & 5 & 4,56 \\
\hline 3 & 001.16 .00007 & 4,67 & 4,5 & 4,61 \\
\hline 4 & 004.17 .00029 & 4,5 & 4 & 4,325 \\
\hline 5 & 001.18 .00035 & 4,167 & 5 & 4,45 \\
\hline 6 & 004.18 .00030 & 4,167 & 5 & 4,45 \\
\hline \multicolumn{5}{|c|}{ Sources: (Agustin, 2019) } \\
\hline \multicolumn{5}{|c|}{$\begin{array}{l}\text { Based on the calculation of the total value of the } \\
\text { performance aspects, the total value obtained fo } \\
\text { each candidate is based on table } 12 \text {. }\end{array}$} \\
\hline \multicolumn{5}{|c|}{$\begin{array}{l}\text { Calculation of the Total Value of Aspects o } \\
\text { Work Culture }\end{array}$} \\
\hline \multicolumn{5}{|c|}{$\begin{array}{l}\text { Based on the formula for calculating the total valu } \\
\text { above, we can calculate the total value of eacl } \\
\text { aspect. The following are calculations from aspect } \\
\text { of work culture: }\end{array}$} \\
\hline $\begin{array}{l}N(b \\
N(k\end{array}$ & $(x) \% N C F(k n$ & $+(x)$ & & \\
\hline
\end{tabular}

Table 12. Value of Total Performance Aspects

Table 13 Value of Total Aspects of Work Culture Work Culture 
JURNAL RISET INFORMATIKA

Vol. 2, No. 2 March 2020

\begin{tabular}{ccccc}
\hline No & NIK & CF & SF & N(bk) \\
\hline 1 & 001.17 .00034 & 5 & 5 & 5 \\
\hline 2 & 001.17 .00030 & 4,67 & 4,5 & 4,61 \\
\hline 3 & 001.16 .00007 & 4 & 4 & 4 \\
\hline 4 & 004.17 .00029 & 4,33 & 4,75 & 4,47 \\
\hline 5 & 001.18 .00035 & 4,33 & 4,5 & 4,39 \\
\hline 6 & 004.18 .00030 & 4,5 & 4,25 & 4,41 \\
\hline
\end{tabular}

Sources: (Agustin, 2019)

Based on the calculation of the total value of behavioral aspects, the total value obtained for each candidate is based on table 13 .

\section{Calculation of Ranking Determination}

The determination of ranking in the Profile Matching method is the final result of the determination of promotion in PT. Hyper Mega Shipping Calculation of ranking can be calculated based on the formula below:

Ranking $=(x) \% N(k n)+(x) \% N(b k)$

Explanation:

N (kn): Performance Value

$\mathrm{N}$ (bk): Values of Work Culture

(x)\%: Percentage Value inputted

Table 14. Determination of Ranking

\begin{tabular}{llllll}
\hline \multicolumn{7}{c}{ Work Culture } \\
\hline No & Nik & N(kn) & N(bk) & Score & Ranking \\
\hline 1 & 001.17 .00034 & 4,71 & 5 & 4,81 & 1 \\
\hline 2 & 001.17 .00030 & 4,56 & 4,61 & 4,57 & 2 \\
\hline 3 & 001.16 .00007 & 4,61 & 4 & 4,39 & 5 \\
\hline 4 & 004.17 .00029 & 4,325 & 4,47 & 4,37 & 6 \\
\hline 5 & 001.18 .00035 & 4,45 & 4,39 & 4,42 & 4 \\
\hline 6 & 004.18 .00030 & 4,45 & 4,41 & 4,43 & 3 \\
\hline
\end{tabular}

Sources: (Agustin, 2019)

Based on the ranking calculation for each candidate, the score obtained for each candidate is based on table 14.

\section{Research result}

The final results of this study were the selection of the top five people. In the 6th rank is occupied by employees with NIK $004.17,00029$, in the 5th rank is occupied by employees with NIK 001.16 .00007 , in the 4th rank is occupied by employees with NIK 001.18,00035, in the 3rd rank is occupied by employees with NIK 004.18,00030, in the second rank is occupied by employees with NIK 001.17,00030, and in the first rank is occupied by employees with NIK $001.17,00034$. The results obtained can be seen in the graph below.

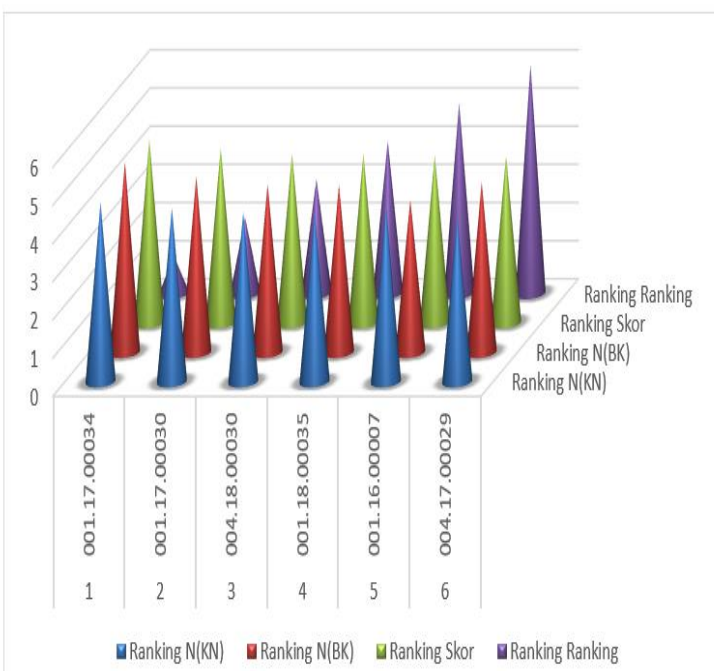

Sources: (Agustin, 2019)

Figure 2. Final Research Results

\section{CONCLUSIONS AND SUGGESTIONS}

\section{Conclusion}

Based on the results and discussion described, several conclusions can be drawn as a result of the research as follows; Profile Matching Method can be used as an alternative decision support system in determining the appointment of permanent employees at PT. Hyper Mega Shipping. So, using the Profile Matching method can help in determining a decision. The process of determining employee rankings calculated using the Profile Matching method starts with determining the Gap, weighting the Gap value, grouping core factors and secondary factors, calculating the total value, and finally ranking. From the research results, which are seen from the aspects of performance and aspects of work culture, along with other criteria and by using the Profile Matching method, employees with NIK 001.17.00034 get the first rank with a score of 4.81 and have the opportunity to become permanent employees. Thus, to get a promotion to hire permanent employees not only be seen from one criterion but also must have a good performance and work culture.

\section{Suggestion}

For further research, a decision support system program was made to more easily manage 
data and be more accurate. We recommend that in the process of determining permanent employee decisions, all employees are included so that all employees are more active in working to be selected for permanent employee decisions. In determining the choice of permanent employees at PT. Hyper Mega Shipping only looks at Work Performance and Culture without considering other criteria to become permanent employees, therefore it is considered important for the future of PT. Hyper Mega Shipping uses a decision support system to get more competitive and productive employees.

\section{REFERENCES}

Agustin, F. (2019). Final Thesis Research Report. Jakarta.

Handayani, R. I. (2017). SISTEM PENDUKUNG KEPUTUSAN PEMILIHAN KARYAWAN BERPRESTASI DENGAN METODE PROFILE MATCHING PADA PT. SARANA INTI PERSADA (SIP). Jurnal Pilar Nusa Mandiri, 13(1), 28-34. https://doi.org/10.33480/PILAR.V13I1.11

Indriyani, F. (2019). PENERAPAN METODE PROFILE MATCHING SEBAGAI PENDUKUNG KEPUTUSAN PEMILIHAN JURUSAN PADA SMK AL HIDAYAH. Jurnal Riset Informatika, $1(2)$, $35-40$. https://doi.org/10.34288/jri.v1i2.31

Pratiwi, H. (2016). Buku Ajar Sistem Pendukung Keputusan. Yogyakarta: Deepublisher.

Purwanto, H. (2017). PENERAPAN METODE PROFILE MATCHING DALAM SISTEM
PENDUKUNG KEPUTUSAN PENILAIAN KINERJA KARYAWAN PADA PT. HYUNDAI MOBIL INDONESIA CABANG KALIMALANG. Jurnal Techno Nusa Mandiri, 14(1), 15-20.

Ramadhan, M. R., Yuniati, Y., \& Bakar, A. (2014). ANALISIS BEBAN KERJA DAN PENGUKURAN GAP KOMPETENSI TEKNISI LABORATORIUM UMUM DAN FAKULTAS TEKNOLOGI INDUSTRI ITENAS | Ramadhan | REKA INTEGRA. Reka Integra, Jurnal Online Teknik Industri Itenas, 2(3), 384-395. Retrieved from https://ejurnal.itenas.ac.id/index.php/rekain tegra/article/view/563

Sinurat, O. R., Irawan, E., Dewi, R., Andani, S. R., \& Fauzan, M. (2019). Analisa Algoritma Profile Matching dalam Menentukan Anggota Security Terbaik di PTPN IV Unit Usaha Marjandi. In Prosiding Seminar Nasional Riset Information Science (SENARIS) (pp. 573-580). Pematang Siantar: STIKOM Tunas Bangsa.

Sugiyono. (2017). METODE PENELITIAN KUANTITATIF, KUALITATIF, DAN R\&D (Buku). Bandung: ALFABETA.

Sunarti, S. (2017). Sistem Pendukung Keputusan Penilaian Kualitas Kinerja Karyawan Menggunakan Profile Matching (Studi Kasus: Apartemen Senayan Jakarta). Techno.Com, 17(1), 103-110. https://doi.org/10.33633/tc.v17i1.1607

Tharo, Z., \& Utama Siahaan, A. P. (2016). Profile Matching in Solving Rank Problem. IOSR Journal of Electronics and Communication Engineering, 11(05), 73-76. https://doi.org/10.9790/2834-1105017376 